\title{
Biological control of root-knot nematode Meloidogyne incognita infesting cucumber Cucumis sativus L. cvs. Alfa by the nematode-trapping fungus Dactylaria brochopaga under field conditions
}

\author{
E.M. A. Noweer and H.Z. Aboul-Eid \\ Nematology Unit, Plant Pathology Dept., National Research Center, Giza, Egypt. \\ ABSTRACT \\ Microbial control of root-knot nematode Meloidogyne incognita infesting cucumber Cucumis \\ sativus L. cvs. Alfa by using the nematode-trapping fungus Dactylaria brochopaga Drechsler, \\ 1937 alone or mixed with yeast or molasses is reported under an open field experiment. The data \\ revealed that the nematode-trapping fungus $D$. brochopaga alone or in combination with yeast, \\ molasses and vermiculite reduced the juvenile-Meloidogyne incognita-population density per one \\ $\mathrm{kg}$ soil and number of root-galls per one gm roots. Weight of cucumber fruits per plant was \\ significantly $(P \leq 0.05$ and/or $P \leq 0.01)$ increased in each fungus treatment compared to the \\ untreated diseased check.
}

Key words: Microbial control, nematode-attraping fungi, Dactylaria brochopaga, Meloidogyne incognita. yeast, molasses, vermiculite, cucumber.

\section{INTRODUCTION}

The history of attempts to use predaceous fungi to control plant- parasitic nematodes had been the subject of several reviews.

The classical work in that area was carried out by Linford and Yap (1938). They added chopped green pineapple tops to nematode infested soil in pots and estimated nematode populations and the activity of the predaceous fungi.

Niblack and Hussey (1986) reported that a nematode- trapping fungus, $A$. amerospora, combined in three commercial preparations with Rhizobium japanicum inoculum's was evaluated for control of Heterodera glycines on soybean (Glycine max) in the field and greenhouse. He found that $A$. amerospora was not considered a probiocontrol agent for Heterodera_glycines on soybean.

In a greenhouse experiment conducted to evaluate the effect of nematophagous fungi Arthrobotrys oligospora and pigeon droppings as a soil amendment on the population dynamics of Meloidogyne incognita on Muskmelon, Ali (1990) indicated that there was a trend towards nematode population decrease with greater efficiency when the fungus was introduced into soil 2 weeks prior to planting and nematode inoculation. Inoculum density of $A$. oligospora was positively correlated with number of juveniles and galls per gram of root before treatment.
Hertz and Dackman (1992) reported that conidia of $A$ . oligospora germinated directly into adhesive traps when applied close to cow faeces on water agar plates, the conidial trap is considered a survival structure enabling the fungus to overcome fungistasis. Traps adhere to the surface of passing nematodes, thus facilitating the spread of the fungus, before penetration of the nematode cuticle and immobilization of the nematode take place.

The fungi $A$. dactyloides, A. oligosora, Macrosporium ellipsosporium, and $M$. cionopagum, killed most of the Pratylenchus penetrans adults and juveniles added to the fungus cultures (Timper and Brodie, 1993).

Anter et al. (1994) found that, in a greenhouse experiment, $A$. conoides and $A$. oligospora showed the highest effect on reducing $M$. incognita numbers during the first 4 weeks. $A$. oligospora and $A$. conoides showed high effect on the activity of the second stage juvenile of $M$. incognita compared to the control treatment (El-sawy, 1994).

Granular formulations of Dactylella candida and Arthrobotrys dactyloides were prepared by encapsulating different quantities of fungal biomass in alginate, or by subjecting encapsulated biomass to further fermentation. Results of experiments with these formulations showed that the presence of nutrients and the quality and quantity of biomass in granules determined their level of activity against nematodes (Stirling and Mani, 1995). 
Arthrobotrys oligospora, A. conoides, Arthrobotrys sp., Dactylaria shelensis, Dactylaria sp. And Monacrosporium bembicodes were tested by Duponnois et al., (1997) for their trapping ability against Meloidogyne mayaguensis. Most of the Arthrobotrys strains and one Dactylaria strain decreased the development of the nematodes. The growth of the tobacco plants was consequently improved, but certain fungi have proper phytostimulant effects by acting on the soil structure through commesalism mechanisms with the plant roots.

An Egyptian population of Dactylaria brochopaga proved to be more effective nematode-antagonist and affecting nematode population larvae through production of traps which capture the larvae and dissolve nematode outer cuticle and digest the inner content of the victim (Aboul-Eid, 1963, Aboul-Eid et al. 1997, and Aboul-Eid et al. 2002).

In the present study, the effect of the fungus D.brochopaga alone or mixed with yeast, molasses and vermiculite as carrier media on the development and reproduction of Meloidogyne incognita in cucumber and growth of cucumber plants is reported under open field conditions.

\section{MATERIALS AND METHODS}

This experiment was carried out through out the period January 24- May 7, 2011 in El-Mansouria village, Giza governorate Egypt. Pre- treatment soil samples were taken, on January 24,2011 at the rate of one stratified soil sample (200 gm), composed of three simple samples (65 gm/sample) from each three rows per treatment. On January 25, 2011, seeds of cucumber Cucumis sativus L. cvs. Alfa were planted. The fungus was introduced into soil by one of three ways: first, spores and broadcasted mycelia carried on agar substrate were incorporated into soil to a depth of three cms under seed spot; Secondly, spores and broadcasted mycelia carried on agar and vermiculite substrate were incorporated into soil to a depth of three cms under seed spot and Thirdly: spores and broadcasted mycelia carried on agar and vermiculite substrate with yeast and molass were incorporated into soil to a depth of three $\mathrm{cms}$ under seed spot. Out of these three application ways eight separate treatments were made as described in Table (1).

Table (1): Type and dose of the nematode-trapping fungus Dactylaria brochopaga and the other treatments in a cucumber open- field experiment.

\begin{tabular}{|c|c|c|}
\hline Treatments & $\begin{array}{l}\text { Type of } \\
\text { application }\end{array}$ & Concentration/spot \\
\hline 1 & $\begin{array}{l}\text { Fungus carried on agar } \\
\text { substrate }\end{array}$ & $2 \mathrm{gm}^{*}$ \\
\hline 2 & $\begin{array}{l}\text { Fungus carried on agar and } \\
\text { vermiculite substrate }\end{array}$ & 2gm(Fungus)+3gm(Vermiculite) ${ }^{*}$ \\
\hline 3 & $\begin{array}{l}\text { Fungus carried on agar and } \\
\text { vermiculite with yeast and } \\
\text { molasses substrate }\end{array}$ & $\begin{array}{l}\text { 2gm(Fungus)+3gm(Vermiculite) } \\
+1 \mathrm{gm}(\text { Yeast })+1 \mathrm{ml}(\text { Molasses })^{*} .\end{array}$ \\
\hline 4 & Vermiculite with yeast & $3 g m($ Vermiculite $)+1$ gm $(\text { Yeast })^{*}$ \\
\hline 5 & Vermiculite with molasses & $3 \mathrm{gm}($ Vermiculite $)+1 \mathrm{ml}(\text { Molasses })^{*}$ \\
\hline 6 & Vermiculite alone & 3gm(Vermiculite) * \\
\hline 7 & Furadan G. & $1 \mathrm{gm}^{*}$ \\
\hline 8 & Untreated control & Without addition \\
\hline
\end{tabular}

*before planting 
A randomized complete block design with three replications per treatment was used at each of the fields and each replicate of three rows. Soil and cucumber root samples of each treatment were taken at $10 \mathrm{~cm}$ depth. Number of Root-knot $\mathrm{J}_{2}$ in one $\mathrm{kgm}$ soil were extracted by sieving and decanting technique (Goodey, 1963) counted using a researcher microscope and collaborated to $1 \mathrm{~kg}$ soil. Root samples were gently washed and galls were counted and collaborated to $5 \mathrm{~g}$ roots. Nematode identification was made to species after referring to the taxonomic references of Jepson, Susan B. (1987). At harvest time the yield obtained was determined periodically several times for each particular treatment and the average weight of fruits were recorded. Percentage reduction in Root-knot $J_{2}$ population in soil were determined according to the formula of Handerson \& Tilton (Puntener, 1981) where $\% \mathrm{Re}=\%$ reduction (\%efficiency).

$$
\mathrm{R} \%=\frac{1-\mathrm{J} 2 \text { population the treated plots after application }}{\mathrm{J}_{2} \text { population the treated plots before application }} \times \frac{\mathrm{J}_{2} \text { population the check plots before application }}{\mathrm{J}_{2} \text { population the check plots after application }}
$$

Data on population densities of $\mathrm{M}$. incognita in both soil and root samples taken from the three replicates per treatment on March 15, and May7, 2011 together with weight of cucumber yield per treatment were recorded and analysed statistically.Data were analyzed statistically using Duncan's Multiple Range Test (Duncan, 1955).

\section{RESULTS}

Effects of the fungus $D$. brochopaga alone or compound with non-chemical materials on reproduction of root-knot nematode $M$. incognitainfested cucumber Cucumis sativus L. cvs. Alfa plants are shown in tables $(2,3)$.

Data in table (2) reveals that the highest decreased $(P=0.05)$ in the number of larvae per one $\mathrm{kgm}$ soil were shown with treatment by fungus $(D$. brochopaga) carried on agar and vermiculite with yeast and molasses substrate.

On March 15, 2011: The number of larvae per kgm soil was decreased in almost all treatments as it was $66,108,132,192,418$ and 432 larvae per kgm for Fungus carried on agar and vermiculite with yeast and molasses substrate, Fungus carried on agar and vermiculite substrate, Fungus carried on agar substrate, Furidan G., Vermiculite with yeast and Vermiculite with molasses respectively compared to the). Vermiculite alone (614) and the untreated control (798 On July 5, 2011: The number of larvae per kgm soil was decreased in almost all treatments as it was 38, 96, 118, 668, 822 and 986 larvae per kgm for Fungus carried on agar and vermiculite with yeast and molasses substrate, Fungus carried on agar and vermiculite substrate, Fungus carried on agar substrate, Vermiculite with yeast, Vermiculite with molasses and Furidan G. respectively compared to the Vermiculite alone (1128) and the untreated control (1842).

The mean percentage reduction of the number of larvae per one $\mathrm{kgm}$ soil were $88.6 \%, 85 \%, 80.4 \%$,
61.8 and 58.5 for Fungus carried on agar and vermiculite substrate, Fungus carried on agar substrate, Fungus carried on agar and vermiculite with yeast and molasses substrate, Vermiculite with yeast and Vermiculite with molasses respectively compared to Vermiculite alone (29.5\%), Furidan G. $(17.4 \%)$ and the untreated control $(0 \%)$.

Data in table(3) revealed that the highest decrease in the number of root-galls per $5 \mathrm{gm}$ roots was noted with treatment by the fungus carried on agar and vermiculite with yeast and molasses substrate.

On March 15,2011 : The number of root-galls per $5 \mathrm{gm}$ roots were 2, 4 and 8 for Fungus carried on agar and vermiculite with yeast and molasses substrate, Fungus carried on agar and vermiculite substrate and Fungus carried on agar substrate respectively compared with Furidan (19), Vermiculite with yeast (22), Vermiculite with molasses (24), untreated control (28) and Vermiculite alone (32).

On July 5, 2011: The number of root-galls per $5 \mathrm{gm}$ roots were 4, 9, 12 and 24 for Fungus carried on agar and vermiculite with yeast and molasses substrate, Fungus carried on agar and vermiculite substrate and Fungus carried on agar substrate and Furidan G. respectively compared with Vermiculite with yeast (48), Vermiculite with molasses (62), untreated control (82) and Vermiculite alone (88).

The mean percentage reduction of the number of root-galls per $5 \mathrm{gm}$ roots were $94.1 \%, 87.6 \%, 78.7 \%$ and $52.1 \%$ for Fungus carried on agar and vermiculite with yeast and molasses substrate treatment, Fungus carried on agar and vermiculite substrate, Fungus carried on agar substrate and Furidan G. respectively compared to Vermiculite with yeast $(32.8 \%)$, Vermiculite with molasses $(21.1 \%)$, Vermiculite alone (8.3\%) and the untreated control (0\%). 
Agric. Biol. J. N. Am., 2013, 4(4): 435-440

Table 2. Effects of the Fungus D.brochopaga alone or mixed with non-chemical materials on population density of root-knot nematode $M$. incognita larvae infested cucumber plants.

\begin{tabular}{|c|c|c|c|c|c|c|}
\hline \multirow{3}{*}{ Treatment } & \multicolumn{6}{|c|}{ Population density of larvae/one kgm soil } \\
\hline & \multirow{2}{*}{$\begin{array}{c}24 / 1 / \\
2011 \\
\text { Initial No. }\end{array}$} & \multicolumn{2}{|c|}{$15 / 3 / 2011$} & \multicolumn{3}{|c|}{$7 / 5 / 2011$} \\
\hline & & No. * & $\mathbf{R} \%$ ** & No. ${ }^{*}$ & $\mathbf{R} \%$ ** & XR\% *** \\
\hline 1 & 248 & $132 d$ & 79.8 & $118 d$ & 90.1 & 85 \\
\hline 2 & 196 & $108 \mathrm{~d}$ & 84.7 & $96 d$ & 92.4 & 88.6 \\
\hline 3 & 214 & $66 \mathrm{~d}$ & 74.2 & $38 d$ & 86.6 & 80.4 \\
\hline 4 & 188 & $418 \mathrm{c}$ & 59.9 & $668 c$ & 63.6 & 61.8 \\
\hline 5 & 218 & $432 \mathrm{bc}$ & 62.7 & $822 b c$ & 54.2 & 58.5 \\
\hline 6 & 206 & $614 a b$ & 28.9 & $1128 b$ & 30 & 29.5 \\
\hline 7 & 294 & $192 d$ & 82.2 & $986 \mathrm{bc}$ & 47.5 & 17.4 \\
\hline 8 & 224 & $798 a$ & ---- & $1542 a$ & ---- & ---- \\
\hline
\end{tabular}

*Data with the same letter(s) within a column are not significantly different according to Duncan s a new

multiple range tests.

** \% Red. = \% reduction (\% efficiency) according to Anderson \& Tilton formula (Puntener, 1981):

$=1-$ No.J2 of the treated plots after application $\quad$ No.J2 of the check plots before application $\quad \times 100$

No.J2 of the treated plots before application $x$ No J2 of the check plots after application ${ }^{* * *} \mathrm{XR}=$ Mean reduction due to treatments.

Table 3. Effects of the Fungus D.brochopaga alone or mixed with non-chemical materials on galls number of rootknot nematode $M$. incognita larvae infesting cucumber plants.

\begin{tabular}{|c|c|c|c|c|c|}
\hline \multirow{3}{*}{ Treatment } & \multicolumn{5}{|c|}{ Number of galls/5gm roots } \\
\hline & \multicolumn{2}{|c|}{$15 / 3 / 2011$} & \multicolumn{3}{|c|}{$7 / 5 / 2011$} \\
\hline & No. * & $\mathbf{R} \%$ ** & No. * & $\mathbf{R} \%$ ** & $\mathbf{X R} \%{ }^{\star \star \star}$ \\
\hline 1 & $8 \mathrm{c}$ & 71.4 & $12 \mathrm{~d}$ & 86 & 78.7 \\
\hline 2 & 4c & 85.7 & $9 d$ & 89.5 & 87.6 \\
\hline 3 & $2 \mathrm{~d}$ & 92.9 & $4 \mathrm{~d}$ & 95.3 & 94.1 \\
\hline 4 & $22 \mathrm{~b}$ & 21.4 & $48 b$ & 44.2 & 32.8 \\
\hline 5 & $24 a b$ & 14.3 & $62 \mathrm{~b}$ & 27.9 & 21.1 \\
\hline 6 & $32 a$ & 14.3 & $88 \mathrm{a}$ & 2.3 & 8.3 \\
\hline 7 & $19 \mathrm{~b}$ & 32.1 & $24 c$ & 72.1 & 52.1 \\
\hline 8 & $28 \mathrm{a}$ & ---- & $86 a$ & ---- & ---- \\
\hline
\end{tabular}

*Data with the same letter(s) within a column are not significantly different according to Duncan's a new multiple range tests.

** \% Red. = \% reduction (\% efficiency) according to Anderson \& Tilton formula (Puntener, 1981):

$=1-$ No.J2 of the treated plots after application $\quad$ No.J2 of the check plots before application $\quad \times 100$

No.J2 of the treated plots before application $x$ No J2 of the check plots after application

${ }^{\star * \star} \mathrm{XR}=$ Mean reduction due to treatments. 
Table 4. Effects of the Fungus D.brochopaga alone or mixed with non-chemical materials on production of cucumber plants infested with the root-knot nematode $M$. incognita.

\begin{tabular}{|c|c|c|c|c|}
\hline Treatment & $\begin{array}{c}\text { Number of plant/ } \\
\text { treatment }\end{array}$ & $\begin{array}{c}\text { *Mean of weight fruits/ } \\
\text { treatment }\end{array}$ & $\begin{array}{l}\text { *Mean of weight } \\
\text { fruits/plant }\end{array}$ & ${ }^{\star *}$ Increase \% \\
\hline 1 & 45 & $94.5 b$ & $2.1 \mathrm{bc}$ & 75 \\
\hline 2 & 45 & $99 b$ & $2.2 \mathrm{~b}$ & 83.3 \\
\hline 3 & 46 & $128.8 \mathrm{a}$ & $2.8 \mathrm{a}$ & 133 \\
\hline 4 & 44 & $83.6 \mathrm{bc}$ & $1.9 c$ & 58.3 \\
\hline 5 & 42 & $75.6 c$ & $1.8 \mathrm{~cd}$ & 50 \\
\hline 6 & 42 & $67.2 c$ & $1.6 \mathrm{~d}$ & 33.3 \\
\hline 7 & 45 & $94.5 b$ & $2.1 \mathrm{bc}$ & 75 \\
\hline 8 & 45 & $54 d$ & $1.2 \mathrm{e}$ & $\begin{array}{c}--- \\
\end{array}$ \\
\hline
\end{tabular}

${ }^{*}$ Data with the same letter(s) within a column are not significantly different according to Duncan s a new multiple range test.

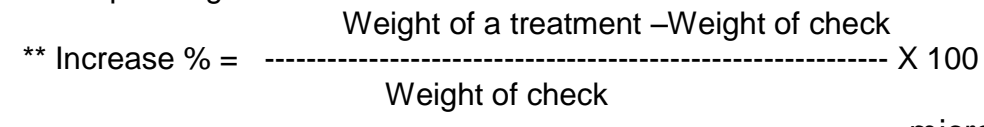

The fruit production of cucumber plants were also affected due to the fungus $D$. brochopaga and its mixtures (table4). The fresh weight increase were achieved by Fungus carried on agar and vermiculite with yeast and molasses substrate treatment (133\%), Fungus carried on agar and vermiculite substrate(83.3\%), Fungus carried on agar substrate(75\%), Furidan G.(75\%), Vermiculite with yeast $(58.3 \%)$, Vermiculite with molasses $(50 \%)$ and Vermiculite alone $(33.3 \%)$ respectively compared to the untreated control $(0 \%)$.

\section{DISCUSSION}

The present results indicate that the fungus Dactylaria brochopaga alone or in combination with the nonchemical materials affected the development and reproduction of Meloidogyne incognita on cucumber under field conditions. This was indicated by the lower numbers of juveniles in soil, lower numbers of root-galls per $5 \mathrm{gm}$ roots, the \% reduction in population density of soil larvae, in treatment of the nematophagous $D$. brochopaga alone and/or with the non-chemical materials. Aboul-Eid (1963) reported that $D$. brochopaga has constricting rings responsible for nematode capturing through trapping mechanism. The fungus proved to be more effective nematode-antagonist and may have been affecting nematode population larvae through production of traps which capture the larvae and dissolve the nematode outer cuticle and digest the inner content of the victim (Aboul-Eid et al., 2002). These information's explain the results of this work. Moreover, (Mankau, 1980) stated that the nematodedestroying fungi play a major role in recycling the carbon, nitrogen, and other important elements from the rather substantial of nematodes which browse on

microbial primary decomposers. Certain fungal agents gave similar results in controlling citrus nematode in citrus groves and orchards (Walker, \& Morey, 1999). The results of work with similar formulations of the nematode-trapping fungus Arthrobotrys dactyloides has shown potential as a biological control agent against Meloidogyne javanica in soil microcosms (Stirling and Mani, 1995).

Finally the fungus (D.brochopaga) could be of great impact on the future of biotic and/or organic farming approach especially for the exported crops and other important foodstuff agricultural commodities.

\section{REFERENCES}

Aboul-Eid, H. Z. (1963). Studies on some aspects of nematode biological control M.Sc. thesis, Agric Fac. Cairo Univ. 100pp.

Aboul-Eid, H.Z., Abdel-Bari, N.A., Ameen, H.H. and Noweer, E.M.A. (1997). The morphological features of twelve nematode-antagonistic fungi and the bacterium Pasteuria penetrans isolated from El-Mansouria region soils (Giza, Egypt). Egyptian Journal of Agronematology 1(1); 59-76.

Aboul-Eid, H.Z.; Fatma. M. Hammad and E.M.A. Noweer, (2002). Effects of the nematode biocide Dbx-1003 in controlling citrus nematode infecting lemon, and Interrelationship with the co inhabitant fungi Egyptian Journal of Agronematology. 6(1,2) 1-13.

Ali, H.H. A. (1990). The use of Nematode- trapping fungi and organic amendments to control root- knot nematodes, Bull. Fac. of Agric, Univ., of Cairo. Vol. 41 No. (3) suppl. 1: 1001-1012.

Ali, E.M., S. Eleraki and A.Y. Elgindi (1994). Antagonistic fungi as biological agents for controlling root- knot Meloidogyne incognita on tomato. Proceeding of 
second International Symposium of the Afro-Asian Society of Nematologists, December 18-22, 1994.

Anter, E. A., S. El-Eraki, E.M. Ali and A.Y. El-Gindi, (1994). Suppression of Meloidogyne incognita infecting Tomato by fungal parasitism during the growing season. Proceeding of second International Symposium of the Afro-Asian Society of Nematologists, December 18-22, 1994.

Drechsler, C., (1937). Some hyphomycetes that prey on free- living terricolous nematodes. Mycologia, 29: 447552.

Drechsler, C., (1941). Some hyphomycetes parasitic on free- living terricolous nematodes. Phytopathology, 31: 773-802.

Duponnois, R., Mateille, T., and Ba, A. (1997). Potential effects of sahelian nematophagous fungi against Meloidogyne mayagyensis on tobacco. Annales- du Tabac- Section-2, No. 29, 61-70; 26 refs.

Duncan, D.B. 1955. Multiple Range and Multiple F. Tests. Biometrics., 11:1-42.

El-Sawy, M.A. (1994). Advanced studies to control plant parasitic nematodes by non-chemical methods. Ph.D. thesis. Dept. of Agric, Zoology \& Nematology. Faculty of Agriculture. Cairo University. 124 pp.

Fresenius, G. (1854). Beitrage zur Mykologie. Heft. 1. Frankfurt a Maing p. 1-38.

Galuilina, E.A. (1951). The predatory Hyphomycetes from soil of the Turkmenistan- Microbiology (Moscow) 20, 6 : 489 .

Goodey, J.B. (1963).Laboratory methods of work with plant and soil nematodes. Tech. Bull. No.2, 72pp.

Hertz B.N and Dackman C. (1992). Conidial traps-a new survival structure of the nematode- trapping fungus Arthrobotrys oligospora. Mycol. Res. 96: 194-198.

Jepson, Susan B. (1987). Identification of root- knot nematodes (Meloidogyne) species. C.A.B. International, U.K. 265 pp.
Linford, M.B. and Yap, F. (1938). Root-knot nematode injury restricted by a fungus. Phytopathology, 29: 2596-609.

Mai, W.F., J. R. Bloom, and T.A. Chen, Eds. (1977). Biology and ecology of the plant parasitic nematode Pratylenchus penetrans. Pennsylvania State University Bulletin No. 815, University Park.

Mankau, R. (1980). Biocontrol Fungi as nematode control. Journal of Nematology 12 (4): 244-252.

Niblack, T.L., Hussey, R.S. (1986). Evaluation of Arthrobotrys ameraspora as a biocontrol agent for Heterodera glycines on soybean. Plant- Disease. Vol. 70 , no. 5, pp. 448-457.

Puntener, W. (1981). Manual for field trials in plant protection. Agricultural Division, Ciba Geigy Limited, Basle, Switzerland, 205 pp.

Rao, G.V. and R.B. Malek. (1973). Effects of nematodetrapping fungi on population of Pratylenchus penetrans. Abstracts from the Proceeding of second International congress of plant pathology, st. Paul, MN. No. 0556.

Rosenj- Zweig, W. D., D. Premachandran, and D. Pramer (1985). Role of trap lectins in the specificity of nematode capture by fungi. Can. J. Microbiol. 31: 69.

Stirling, G.R. and Mani, A. (1995). The activity of nematode-trapping fungi following their encapsulation in alginate. Nemtologica 41 (2): 240-260.

Timper, F. and Brodie. B. B. (1993). Infection of Pratylenchus penetrans by Nematode- Pathogenic Fungi Journal of Nematology 25 (2): 297- 302.

Walker, G. and Morey, B. (1999). Effects of chemicals and microbial antagonists on nematode and fungal pathogens of citrus roots. Austr. J. Experimental. Al Agric. 39: 629-637.

Zopf, W. (1888). Zure kenninis der infections skrankheiten niederer und pflanzen. Nova Acta. Loop. Carol. 42: 313-341. 